\title{
Vision of Vincent van Gogh and Maurice Utrillo in Landscape Paintings and their Impact in Establishing the Identity of the Place
}

DOI: $10.21625 /$ archive.v1i1.133

\author{
Hala Ibrahim Mohamed Elsaed ${ }^{1}$ \\ ${ }^{1}$ Painting Department -Faculty of Fine Arts
}

\section{Keywords \\ Painting \\ Landscape \\ Van Gogh \\ Maurice Utrillo}

\begin{abstract}
There are varieties of visions, visual solutions and plastic relations for various painting topics, but the landscape painting is still the closest subject to the identity of the place.

When the artist translates the realistic features of the place describing it with his special style and touches, this represents a record for characteristics of a certain period related to this place. It might also depict the landscape by his sense, telling us with his painting brush the story of its heritage. The artist links it with the reality experienced -here the memory adds the highest value to the view and translates features of nature of this place in terms of form- or feelings and influence through the ages.

When Van Gogh was influenced by a city, like Arles in France, he produced the most beautiful of his paintings, which appeared to show his style and colors. Actually, we see this city through a creative artist with radiant colors, each panting as a celebration or a poem singing the beauty of this place.
\end{abstract}

And when Maurice Utrillo was influenced by a city -like Paris in France especially Montmartre district with its steep winding streets, picturesque windmills, snowfall, and clouds of gray affected- he created his most important paintings of landscape. The paintings reflected the nature of this place by his simple style which seems like a zap from the internal inventory of the artist about this place.

So this research will address:

- The relationship between" Van Gogh and Maurice Utrillo "and the place.

- Review their famous works that related to those places.

- Clarify their vision and style in painting.

- The impact of their paintings on those places.

\section{Introduction}

Most places have huge reserves of photographs that represent a literal embodiment of the place and show its visual details.Howecer, the artist embodies the spirit of the place in the landscape paintings, and the artisit implicilty reveal the landscap's hertage and civilization through his art. The word "landscape" in Dutch means an area of the earth, but it got its most common technical meaning when it became the painting which depicting a scene on the ground. In most cases, landscape topics include sky and what lies under it, like valleys, hills, trees, buildings, 
rivers, birds, animals and all the landmarks of the place. Each phase experienced by cities left traces in the place and in humans, and it has been never overlooked by the artist's brush.

There is another concept of landscape, meaningly, the cultural landscape. It is a tool to conceptualize the world in a trial to rebuild it. The term does also serve as an idea rich of human values waving a story about the " genius of the place". Also, the idea gives the importance of the value of re- interpretation human connections, like the realtionship between " man and nature" or between " Nature and culture ".

When the artist's imagination and special sensual and emotional experiences penetrate to artistic subjects, it adds a new dimension. Not to mention that nature inspires the artist by its richness of elemenets though.

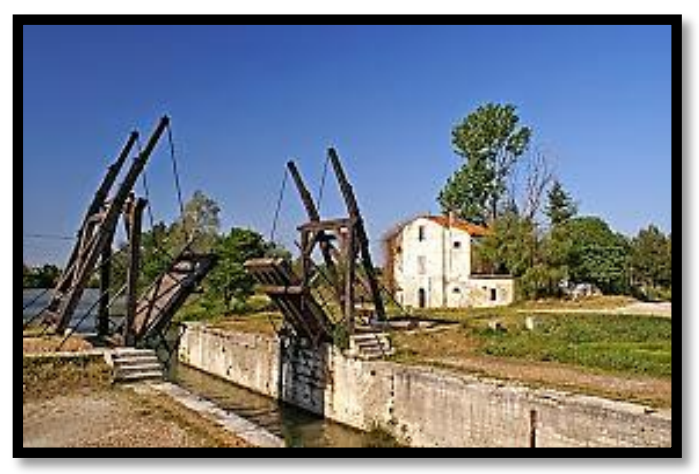

Figure1

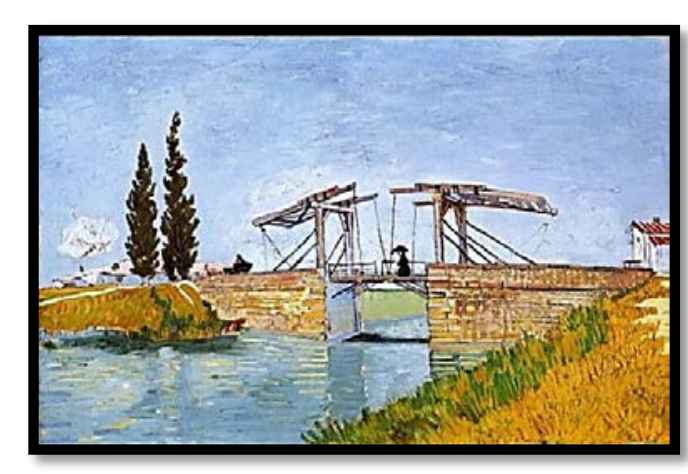

Figure 2

The artist was not only conveying nature as a ready to record truth, but he wa also expressing it in his own way and creates new aesthetic realities in his sensory and emotional figurative paintings.

Each city represents a literary (poetic) unique phenomenon. Therefore, it's difficult to determine general features for cities. Nature and shape differ from place to another because it was created by certain historical events and circumstances making it special. Sometimes, certain -seemingly insignificant- events become important turning points in the history of some cities.

It's not strange that after travelling and moving from country to another, the human might feel likeness, familiarity or passion towards certain places. Moreover, it feels as if the man was born to live there, so he demonstrates his work and art through such places. On another leve, the humanbeing might be a significat feature of the city in which he was born. His expierence in coxisiting or struggling with events is what shapes the trajectoyr.

In this paper, I will display both cases through two artists that had the most sensitivity and connectivity to places. I have chosen them because they have perfectly depicted the landscape through their inner vision reflecting pure, unique, and new feelings in harmony with reality rather than emulating it.

\section{First: The city of Arles and Vincent van Gogh}

Arles is a city in the Provence region of southern France. It is one from the largest cities in France. It has a long history and great importance as it includes many Romanian remains, which were included in 1981 in the UNESCO World Heritage Centre. Moreover, it includes many important tourist attractions, like the Church of St. Trophimus, Arles Amphitheatre, Arles tower and Arles Museum of antiquity. Even on the enviormnental level it has beautiful and charming parks such as Comargue Natural Regional Park

Arles, with its gates, churches, river, architecture, museums, art, poetry and paintings represent the best example of the place's beauty. It is an interesting model for an ancient city adapting with the European civilization during the middle centuries. It has amazing Roman commemorative monuments. Each stone built in the city has a mark from the past. The Rhone river forks into two branches, dividing the city into two parts, where the historical bridge -along with its ancient stones- connects the ancient city with one of the city's modern slum. In other words, it is the perfect trial connecting the two together in order to unvail the city's history of Arles through present events.

Roman architecture had a great impact on how the city looks, there are many examples representing the Roman civilization in France till the second world war. The French carried out renovations for the Roman antiquities, to keep it in its real historical state. There is a beautiful poem written by " Frederic Mistral" (1830-1914), the city poet, in which he flirts the prettiest girl in France, as he sees her in the suburb of the city of Arles. The poet describes his lover's birth place saying that it is a Roman history on a French ground, here the Rhone river runs, where its summer breath cools the atmosphere and its air in winter touch the rain. Each step you make in Arles could represent part of a historical story about one of those ancient great people. 
Langlis Bridge (figure 1) is a moving bridge owned by Arles Tourism Board. It appears in many paintings of Vincent van Gogh that he produced in 1888 ( figure 2). It is one of the most beautiful ten moving bridges. Now, it is one of the most beautiful landmarks visited by many tourists to see its functionailty and wonderfull enfineering. Its common name now is Van Gogh Bridge.

This amazing synergy of history and the present -with special atmosphere- has influenced many artists. But Van Gogh left the greatest impact in this place. For example, at the hospital of Arles, the library hall is the room in which he slept in when his ear was cut. The Slovenian translator Laslo jokes said that if anyone complains of intermittent sleep there or nightmares, it’s the ghost of van Gogh living here and irritating us in our sleep.

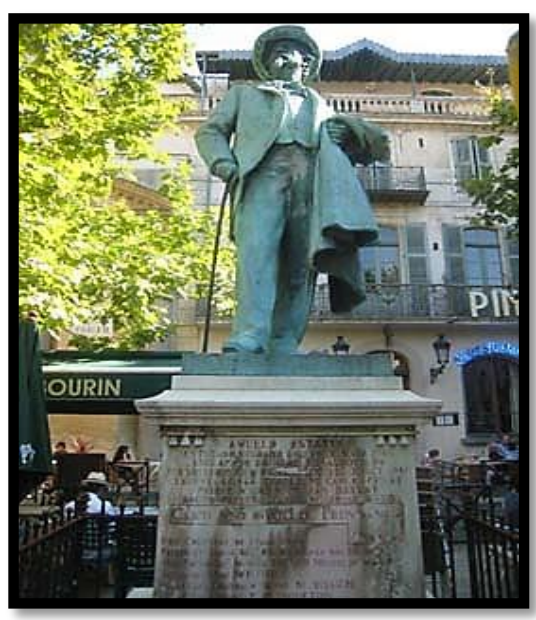

Figure 3

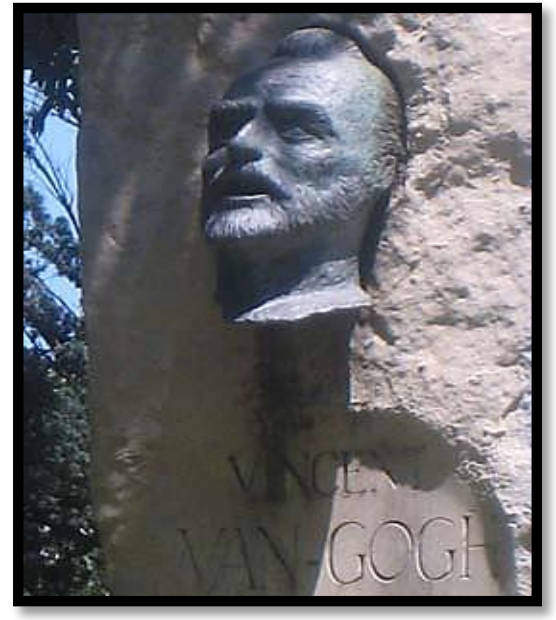

Figure 4

People of the city appreciate those who expressed the beauty of the place using either their words or brushes. There is a statue of the city poet Fredric Mistral and another for the face of van Gogh. The state of pride is noticed in the two statuses (figure 3), (figure 4)

Vincent Willem van Gogh (30/3/1853-29/7/1890) was born in Netherlands. He was named Vincent after his brother who was born dead one year before the birth of Gogh. At the age of sixteen, he worked for the Hague's branch of Goupil \& Cie on July 30, 1869. Goupil\& Cie was an international print publishing firm and art dealer. He exchanged letters with his brother, Theo, throughout his different art stages. These letters served as a way to comprehend Gogh's visions about his life and works.

Van Gogh arrived on 21 February 1888, at the railroad station in Arles, crossed Place Lamartine, and entered the city through the Porte de la Cavalerie.

In Arles, Van Gogh drew a number of his best landscape paintings, he was pleased with what he had produced and felt renovation in his artistic path; life in Arles was happier for him. Early in May, Vincent reserved a room in di La Gar coffee shop, he rented four rooms in a yellow house (figure5). He occupied two large ones on the ground floor to serve as an atelier (workshop) and kitchen. In this house, he kept his paintings and he called it the south atelier. We can see the yellow house in his paintings (figure 6). In Arles, Van Gogh gained self- confidence and he drew wheat fields, large trees, and little flowers trees, that look like the Japanese trees. He also drew many paintings for the moving bridge (Langlis Bridge) (figure 2) from different perspectives. Thus, Arles shared Van Gogh in his best landscape paintings. He wrote a letter to his brother Theo about the city saying:

"Here in Arles, the country seems flat. I have seen splendid red stretches of soil planted with vines, with a background of mountains of the most delicate lilac. The landscapes in the snow with the white summits against a sky as luminous as the snow were just like the winter landscapes that the Japanese have painted “.

He started the landscape subject by painting the Dutch landscape around him. In 1882, he was painting the sea, dunes, and woods of the Netherlands in dark muted earth tones. In these early landscapes of Van Gogh, he was still developing as an artist and was not yet painting in the style that he would be most known for. Van Gogh was painting 


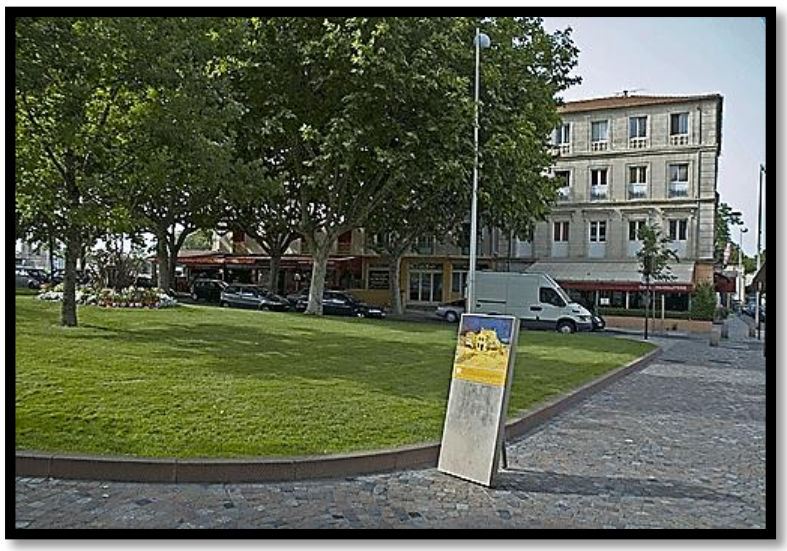

Figure 5

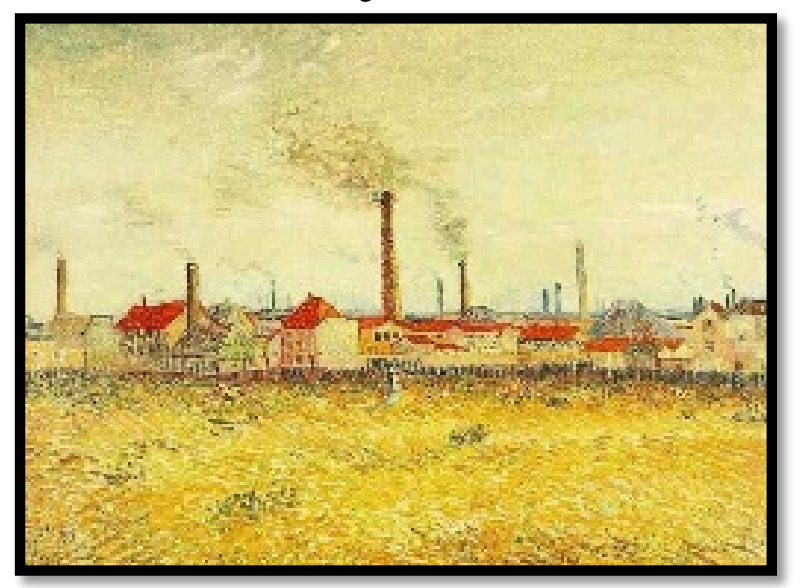

Figure 7

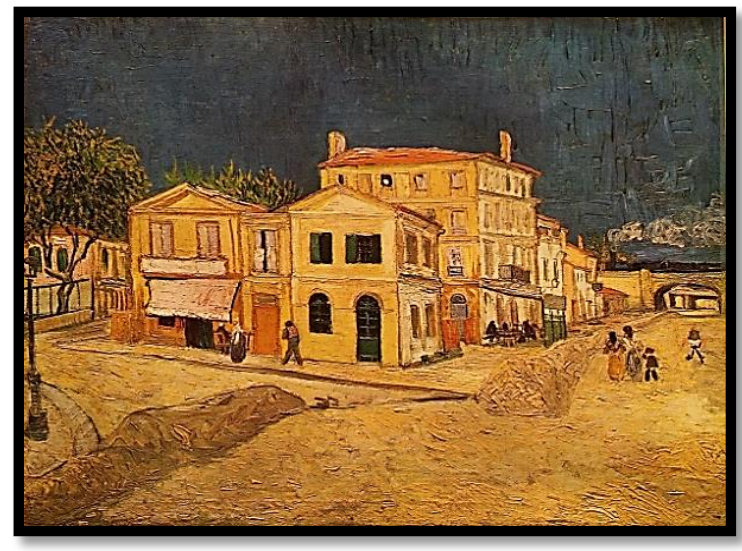

Figure 6

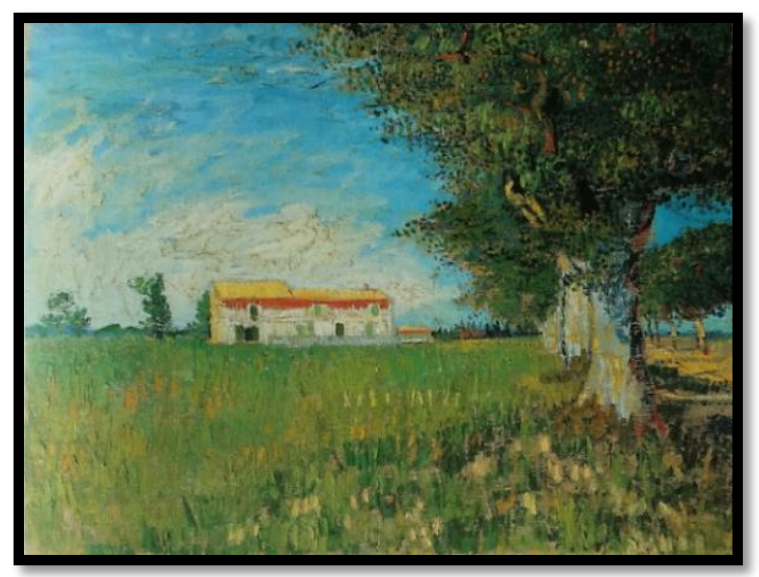

Figure 8

these landscapes and yet, he himself wasn't fully committed to them. He wrote to his brother, Theo,

"I'm certainly no landscape painter. If I were to make landscapes, There would always be something of the figure about them.”

Later, Gogh moved to Paris where he lived with his brother Theo in Montmartre. The Two - year period in Paris was fortuitous for Van Gogh, who was immediately thrust into a milieu of young avant- grade artists experimenting with new styles. He was interested in this period in the Japanese art and impressionist artists. His paintings at this period reflected the vivid usage of colors.

By 1886, Van Gogh started painting scenes of Paris with brighter colors. The following year, in the spring of 1887, he started resorting to much brighter colors with quick animated brush strokes. In Asnières, a suburb of Paris, Van Gogh painted landscapes with new vitality.

One of the themes in Van Gogh's paintings from Asnières was the rise of industrialism and its influence on the rural landscape (Figure7). For Van Gogh, peasant life and that of the agricultural worker were seen as, perhaps, the truest form of living. From the beginnings of his adulthood, when he was exploring vocations in religion, he was always concerned with the workingman. He depicted this subject matter throughout his career, including his landscape paintings. According to Van Gogh's perspective, landscapes are more than depicting a natural setting; they are celebrating nature, those that live within it, and those that work it.

Van Gogh painted his first wheat field in 1885, but in 1888 it became a major subject matter for him. From then on, Vincent painted wheat fields wherever he was in France.

In Arles, Van Gogh painted fields and farmhouses. (Figure 8) " Farmhouse in a Wheat Field " shows a tree growing in an expansive field of growing wheat, before the harvest. In the distance beyond the field, there is a modest white house with a yellow roof lit by the bright sun.

Nature was often the subject of his work. It is true that he often incorporated figures in them, which distances them from traditional landscapes, but the overall effect is quite similar. Van Gogh's landscapes were directly 
related to his thoughts about life and death. Like wheat fields, Van Gogh visited the subject of Cypress and Olive trees to show the

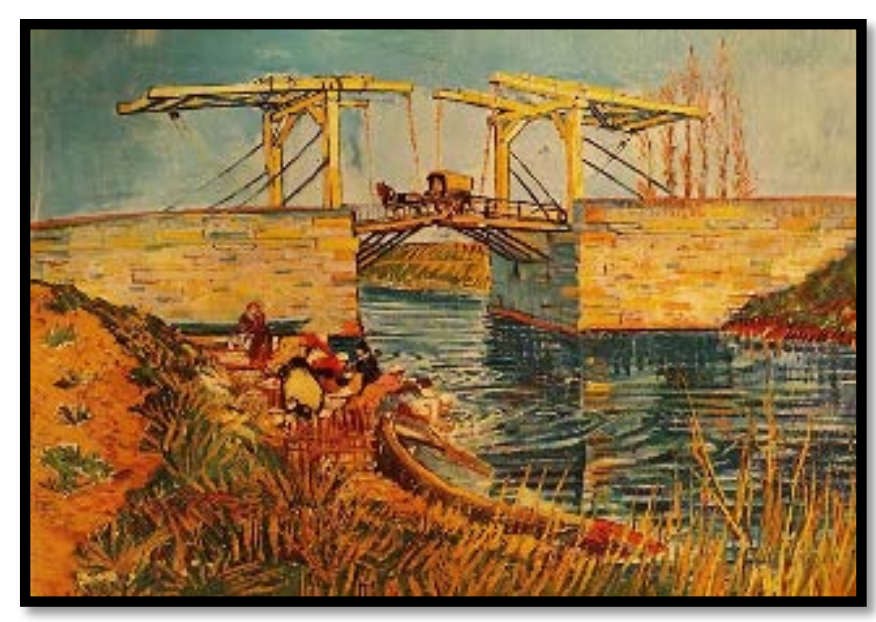

Figure 9

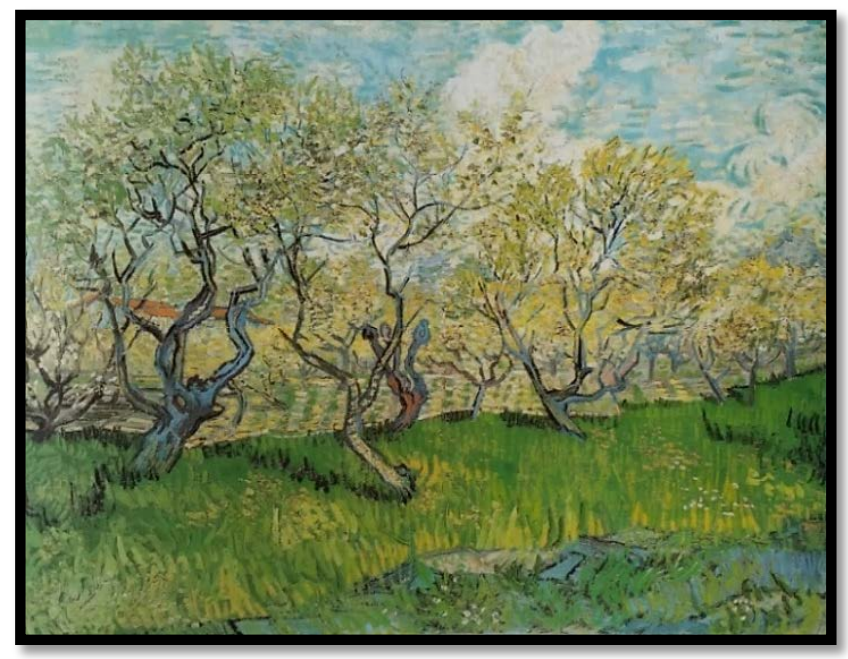

Figure 11

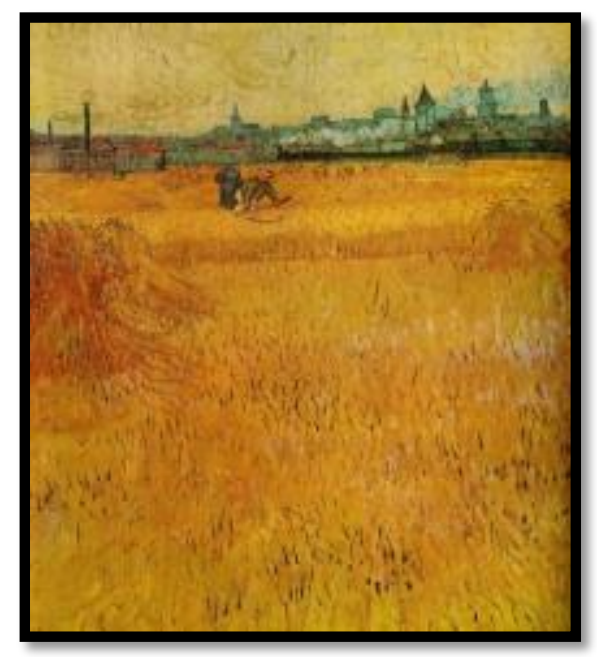

Figure 10

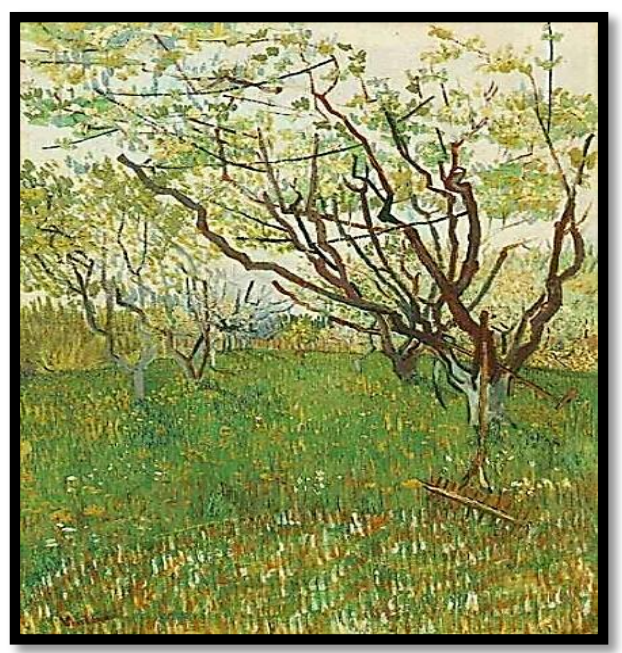

Figure 12

cycles of life, and with the harvesting, death. As someone who struggled with relationships, he still had an acute understanding of people and understood the important relationship people have with nature. His landscapes show that relationship (Figure 9) (Impact, T. N, (n.d.).

He found the South as a spiritual and aesthetic liberation from the increasing claustrophobia of Paris. In spite of the heavy snow, he was filled with optimism, seeing the mountains around the plain of Arles in terms of the Japanese. In his first week, he had already drawn a landscape in the snow. He also explored the two main Arles museums. He rapidly discovered that the surrounding country was arrestingly beautiful in its state of spring budding, with some striking man-made additions, notably the Langlois Bridge (Figure 10). In this unfamiliar landscape, he found in the bridge a reassuring echo of the structure of the old Dutch looms. this landscape is a complete expression of his new art of colour, with complementaries, particularly blue and orange, offsetting each other with dazzling.

Van Gogh was anxious not to miss any of nature's moods and phenomena, Correspondingly, the views of orchards in blossom which he painted shortly after arriving in Arles, have a cheerful springtime atmosphere. But they are more than merely the product of seasonal mood. As if he and the region had colluded on it, he found a world of motifs which could not have been more Japanese. He did not need the Japanese prints anymore as he had done in Paris. The orchards were his utopia, there it was, before his eyes, true, this was also the sum total of oriental character that Arles had to offer, but this series of paintings, completed within the next few weeks, at any rate, confirmed that he had taken the right decision. (Figure 11) and (Figure 12). 
The railway made an occasionasl appearance in his landscape paintings. In "Avenue of plane trees near Arles Station" (The Blue Train) ( Figure 13), mentioned in a litter written by his brother, " the movement of the train is restricted by the bare tree trunks in the foreground, so that it appears more as a part of the compositional grid than as dynamic entity ". The train also appears in various paintings and drawings of Arles from the surrouning wheat fields, where it functions as the dividing line between town and country.

Van Gogh had been living in guest houses ever since he arrived in Arles. He rented a store for the pile of paintings that got accumulated soon. This store was to go down in art history as the ( yellow house). Every morning he would leave his lodgings heavily laden and roam the area in tireless quest of motifs to satisfy his creative urge. He set off to work

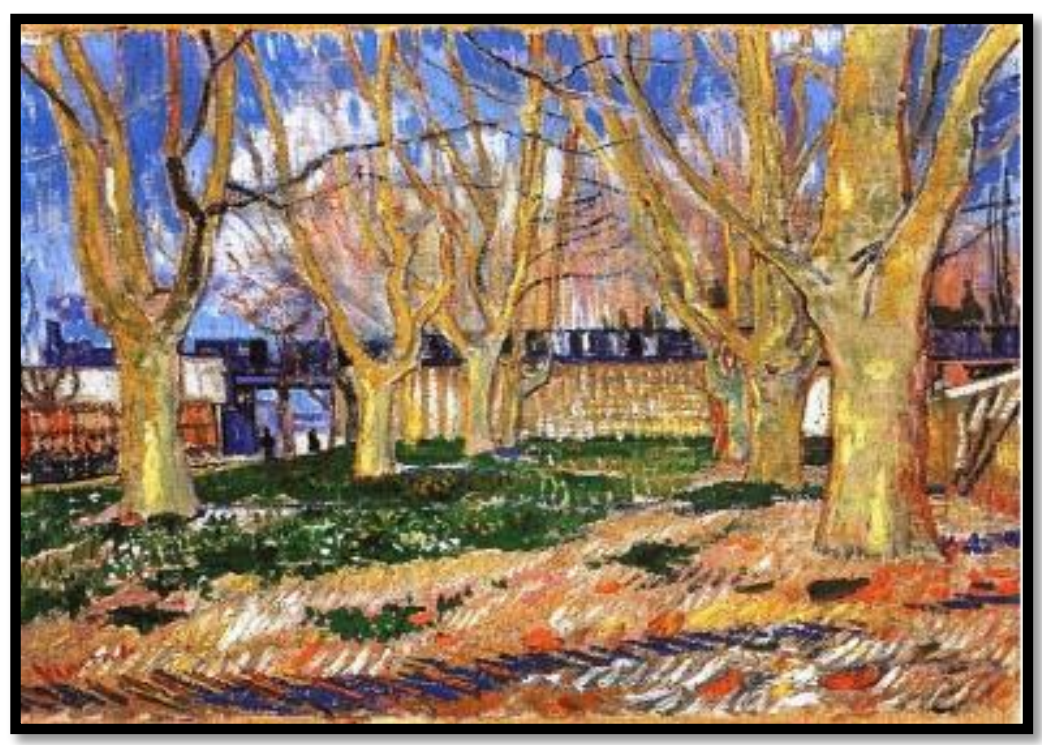

Figure 13

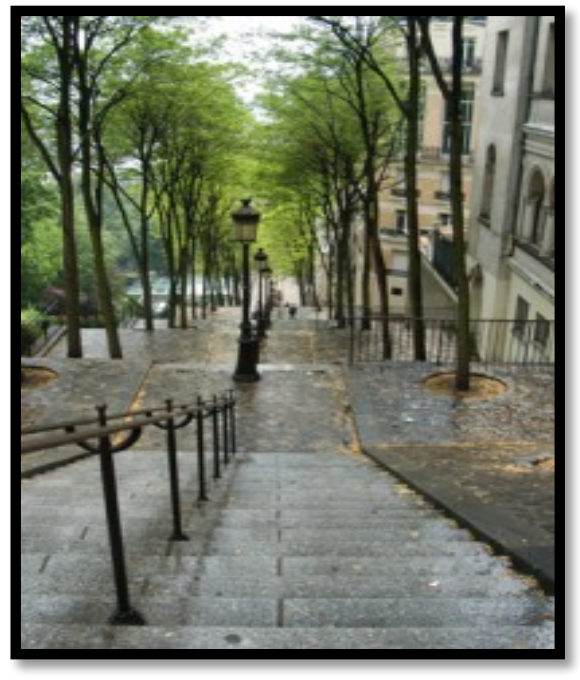

Figure 14

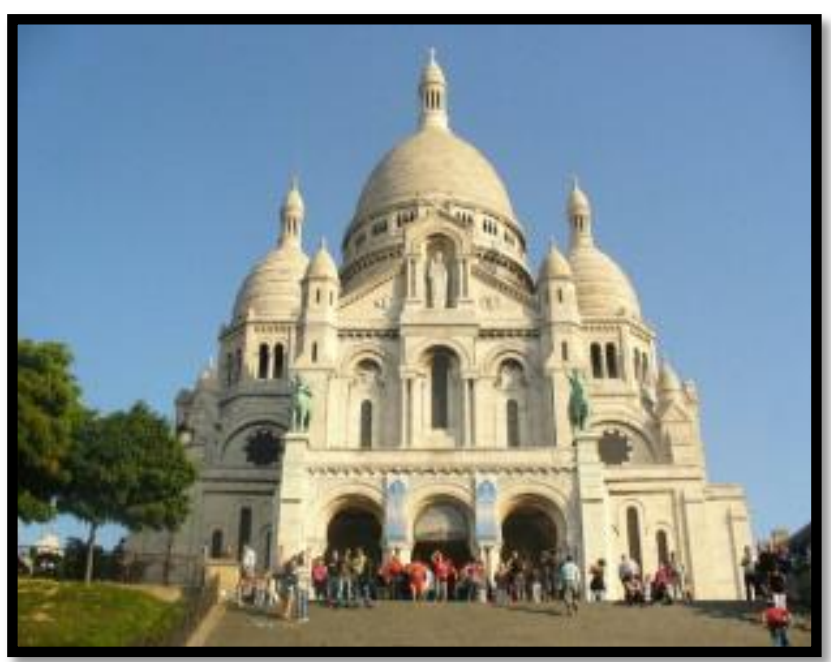

Figure 15

day after day, into the blossoming hilly landscape. He kept producing one masterpiece after another " it is the excitement, the honesty of a response to Natur, that guides our hand, and if this excitement is often so strong that one works without noticing that one is working, if brushstrokes sometimes come thick and fast like words in conversation or letter, then one ought not to forget that it has not always been like that and that there will be many a depressing day barren of inspiration in the futur " these words (from Letter 504).

\section{Second: Montmartre and Maurice Utrillo}

From the city of Arles, we move to one of Paris districts, Montmartre. It is considered one of the most important and special French places which deeply affect artists, like other French places which fascinate artists and writers. Paris, about whom the quote says: "Only who dies in Paris has lived a life", and which intellectual Taha Hussein 
(1889-1973) described as "the capital of ghosts and angels" is the city of life. It is unique in its charm that combines the ancient and the new. Paris is divided into twenty districts, and Montmartre is a special district in Paris. It is a large hill in Paris. It is 130 meters (430 feet) high, it is the high point of Paris (Pessard, 1970). It has narrow lanes forming a charming mosaic in its ups and downs. Its small colorful houses add to the charm of the place and reflect a special attraction. Thus, the quarter appears as a painting with its expressive colors. Thus, the quarter was known as the visual artists' quarter. Throughout the years, Montmartre, along with other ancient French quarters became a tourist attraction at which tourists must stop either to buy a painting or to enjoy watching artists painting at ( place de la latre). Historically speaking, the most famous artists lived and painted there. They chanted throughout the world for that sweet spirit inhibiting the place throughout years. Artists such as Amedeo Modigliani, Claude Monet, Henri de Toulouse-Lautrec, Piet Mondrian, Pablo Picasso, Camille Pissarro, Vincent van Gogh and Salvador Dali whose late atelier was there, later it became a museum. And the whole arena later became a meeting point for artists painting tourists and exhibiting their works at the open air. There are many paintings expressing the spirit of the place and the beauty of its ancient nature. However, I will focus in this paper on the French artist who belongs to Montmartre. Maurice Utrillo (1883-1955), was one of the few famous painters of Montmartre who was born there.

During his stay in Paris at that time, Egyptian writer Twfeek Al Hakeem ( 1898/1987) admired his art. Al Hakeem was known for his love and taste for arts. He wrote about Utrillo saying “ He was simple in a spiritual, captivating sensitivity. He depicts what he likes, and what I like. Such ancient frightening aspects of Montmartre, rarely visited by people, through which I used to wander helplessly during those days of bankruptcy. Utrillo in his paintings perpetuated the old abandoned Montmartre. And if most painters worked on painting human faces, Utrillo was the illustrator of only one face, the face of Montmartre with its wrinkles, using the simplest colors and least clamor. However, he loaded it with feelings, provoking the deepest memories ".

Montmartre is characterized by its zigzag roads and stairs (figure 14) as well as the religious churches such as Basilique du Sacre Coeur, which is a splendid church made of white marble (figure 15). Its internal halls are decorated with golden mosaic. There is also Saint Pierre de Montmartre and the colored elevated windows (figure 16) which still has the ancient French nature. It includes several restaurants, coffee shops, and stores, famous Montmartre mills (figure 17) and narow streets (figure 18) painted by many artists. The city features are not only depicted in paintings, but also many famous international movies were produced in the city. There is a statue for the Egyptian actress Dalida in front of the building were she lived (figure 19) and there are other famous artists and writers. So Montmartre Cemetery is the final resting place of many famous artists who lived and worked in the Montmartre area.

Utrillo was the son of the artist Suzanne Valadon (1865-1938), she was a French painter and artists' model. Valadon grew up in poverty with her mother and didn't know her father. She was known to be quite independent and rebellious.

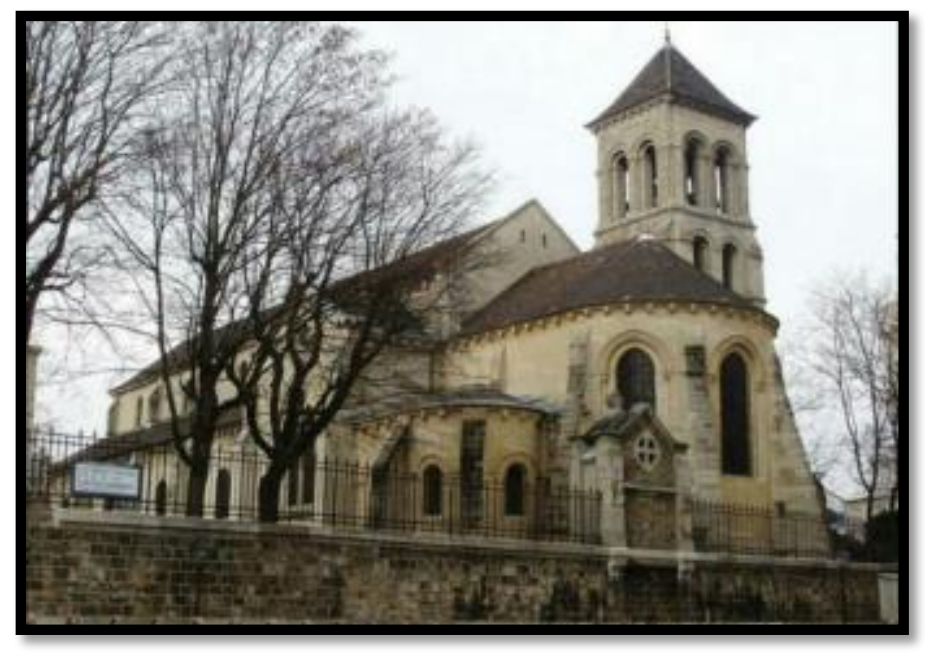

Figure 16

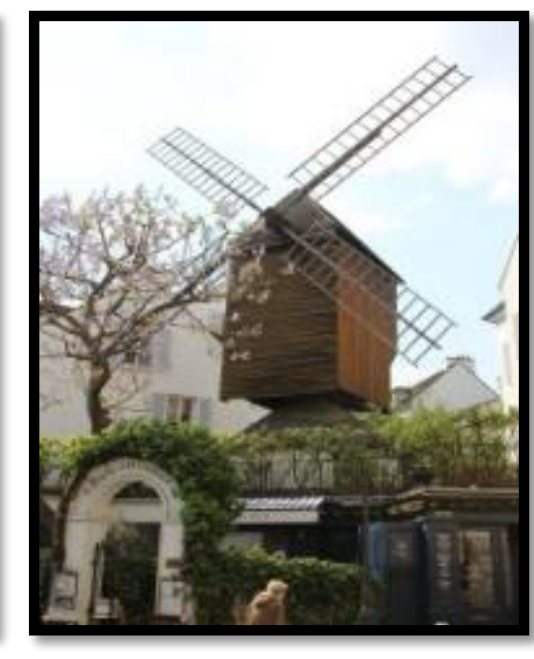

Figure 17

She attended primary school until the age of 11 when she began to work. In 1883, Valadon gave birth to her illegimate son, Maurice Utrillo, at the age of 18. Valadon's mother cared for Maurice while she returned to modelling. Valadon's friend Miguel Utrillo signed papers recognizing Maurice as his son. However, Maurice soon showed a troubling inclination toward truancy and alcoholism. When a mental illness devastated the 21-year-old, Utrillo in 1904, his mother encouraged him to alleviate his pain through painting. He soon showed real artistic talent. With no training beyond what his mother taught him, he drew and painted what he saw in Montmartre. After 1910 
his work attracted critical attention, and by 1920, he was internationally acclaimed. In 1928, the French government awarded him the Cross of the ( Légion d'honneur) (Pregelj, 2012). Throughout his life; however, he was interned in mental asylums (Werner,1953).

In his paintings, Utrillo was interested in the streets of Paris. Montmartre was his favorite, with its sloping streets and amazing wind mills (figure 20). Most of Utrillo's paintings were gloomy and had that touch of sadness. Similarily, the streets in his paintings seem empty except for the isolated shapes. Falling snow and grey clouds leaves a gloomy and depressing effect.

Moreover, what adds to the gloominess of his paintings was his use of the perspective technique. It reveals things as in reality (figure 21) without adding any romantic aspects, like those revealings in most of the paintings by other artists who drew Paris districts. From 1908 till 1914, Utrillo used white colored mixed with soft and different colors. Thus, his works of art went through three stages. During the first stage, he was concerned with the influential tendency led by Pissarro, which is the most important one. The third was the blossoming stage in which he used shining and loud colors. At this stage, he had less control in his brush due to his mental disease.

Utrillo used to paint the church of Saint-Pierre de Montmartre, built in the 12th century. Cœur One of the many versions of this subject, this painting in the Musée de l'Orangerie shows the facade of SaintPierre de Montmartre behind the entrance gate. It is possible that Utrillo took a postcard as his model, for the compositionis is very symmetrical. ( figure 22) Here the artist is keen to express the elements in the composition through different styles of brushwork. The pavement and road are painted with delicate horizontal strokes with alternating light and dark tones as a medium to convey the uneven surface. He uses a thicker impasto, his characteristic white, for the facades of the houses and Saint Peter's church, the domes and the bell tower of Sacré Cœur. As for the sky, it has more compact brushwork reducing the depth.

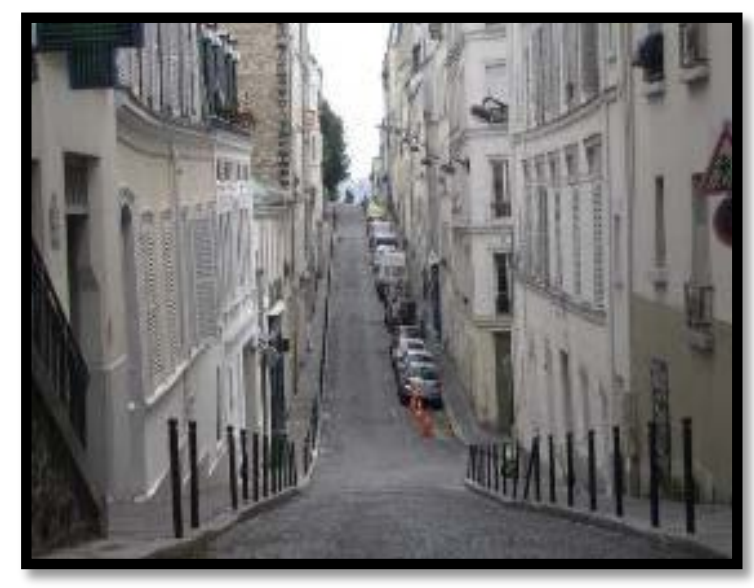

Figure 18

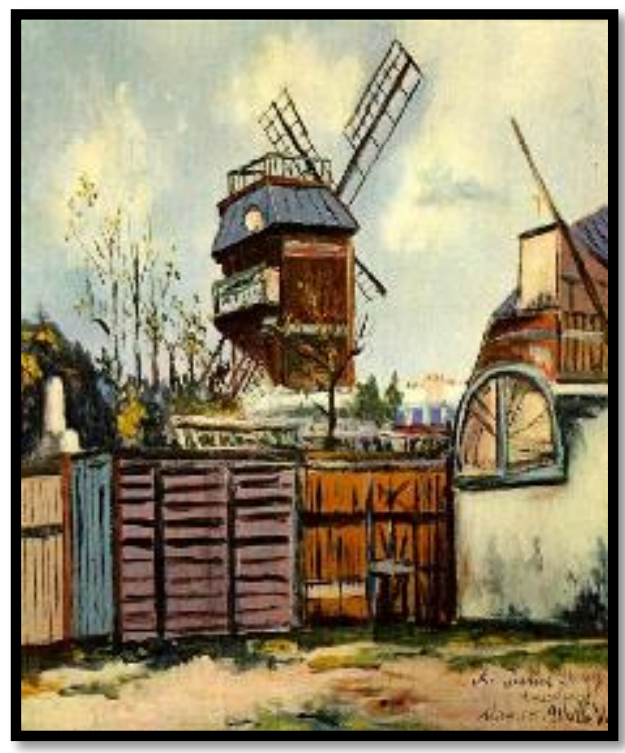

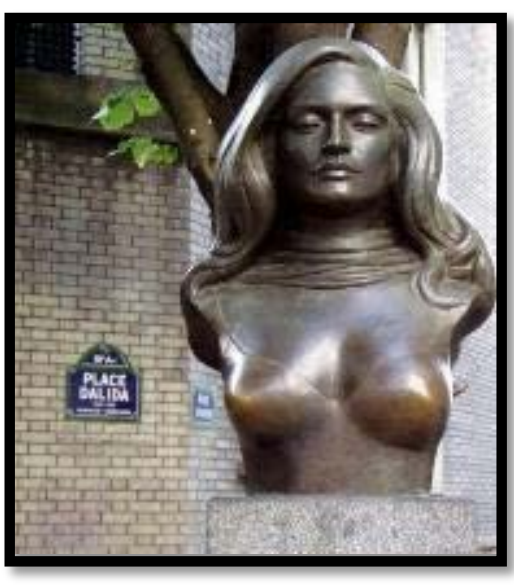

Figure 19

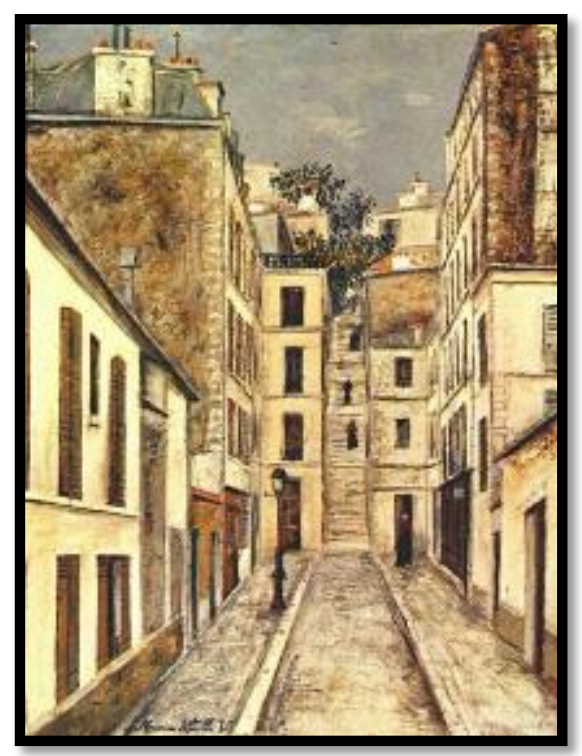


The windows and openings in the buildings are closed or opaque. Only the leaves on the trees, rendered in small green and yellow brushstrokes, bring some life to this scene.

Despite addiction and other psychological problems he went through, Ultrillo continued for many years to produce and draw many landscapes. He is considered more fortunate than other artists in Montmartre as he lived until the age of 72. He continued to draw till his death. His mother and wife played important role in saving him from destroying himself. He was the only one of his three companions who escaped from street life. The companios who died at a younger age are Amedeo Modigliani (1884-1920), Chaim Soutine (1893-1943) and Jules Pascin (1885-1930).

The church at Clignancourt was one of Ultrillo's special paintings ( figure 23). Utrillo has also painted NotreDame de Clignancourt which is built in Montmartre from 1859 to 1863 . Montmartre remained an independent commune for many years, and only became part of the City of Paris in 1860, along with several other villages on the outskirts of the capital. Utrillo had a strong sentimental attachment to this church. In fact, one day he confided :

" I was born in Paris on 25 December 1883, on Christmas night, at 3, Rue du Poteau, next to the church of NotreDame de Clignancourt. This is not a very beautiful church and not very old, and there it is all on its own, but I like it all the same and I have painted it for my mother who looks after it."

We can, therefore, assume that Utrillo did this for his mother, Suzanne Valadon, who was also a painter. It was produced in the studio. The lines were drawn out with a ruler and some are visible on the walls of the church. The perspective here is very accomplished. The church, with its very pale walls, takes up most of the surface characterised by very steady lines. A few silhouetted figures give it a little life. It is an autumn scene as there is a grey sky lowering above the church and a tree with leaves that are already turning red.

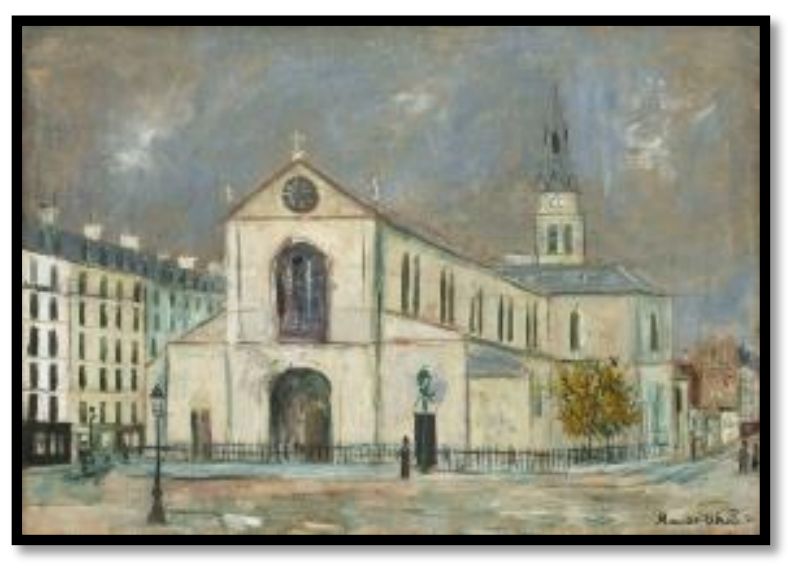

Figure 22

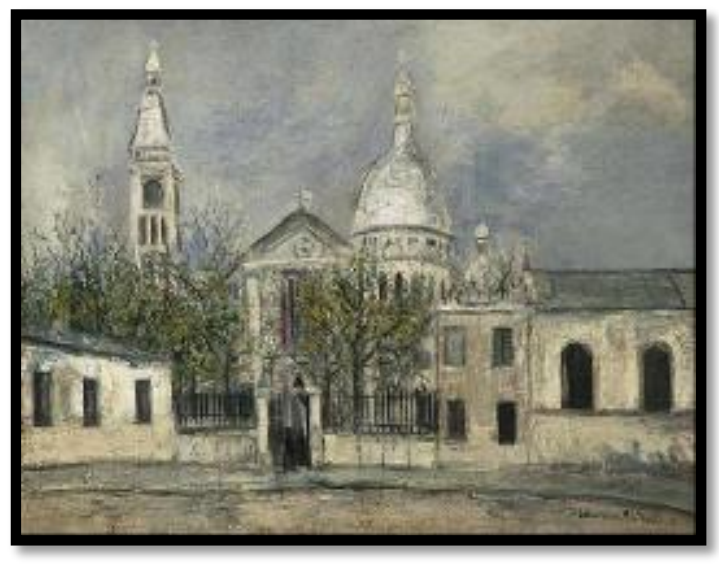

Figure 23

Sacre- Coeur De Montmartre (figure 24). Painting offers a glimpse of the famous church of Sacre-Coeur (Sacred Heart), identified by the immense white dome at the end of the narrow street. The church is the most familiar building of Montmartre, the artistic quarter on the north side of Paris that Utrillo frequented. The loose brushwork and bright color scheme suggest the influence of the Impressionist painters, though Utrillo was more than a generation younger than Monet and Pissarro. This young, half- mad alcoholic of Montmartre, Maurice Utrillo, presented strange landscapes which delighted the man in the street and astonished the connoisseur. These pictures inspired many artists to re-examine their world trying to recreate reality instead of turning it into abstraction.

Utrillo stands at the borderline that separates the "naïve" from the "professional" artist. Ultimately he was somehwat relevant to both. Maurice was shy, weak, and above all neglected boy. A feeling of being abandoned, shut off from the world, augmented his hereditary propensity. Maurice drank and painted, he became the portraitist of Montmartre. In keeping with his background, he began with Impressionism under the tutelage of his mother, whom Degas had taught to paint, but Utrillo had a heavy hand. His division of colors was not methodical, and his art, at least in the early years, lacked all perfectionistic fluency. Artistic problems did not interest him much. Utrillo simply wished to realistically paint the environs in which he lived, not to create art. Impressionism struck him as the best way of approaching reality apart from the fact that he knew no other ways. But reality includes the feelings and moods of the person who perceives it. Utrillo projected such sensations into his pictures. This is the source of their melancholy, occasionally somewhat sentimental poetry, and of the mellowness of their color, especially in the "white period " with its subtle gradation between white and grey. "white and silence are what one must paint, Utrillo told Florent Fels," the color of the barraks, the hospitals, and prisons. My life has run its course in these houses of the lost, in the midst of the white of misery. 
In middle age, Maurice Utrillo became fervently religious and, in 1935, he married artist Lucie Valore. She is a friend of his mother, who was very supportive of the marriage. Lucie was very devoted to her husband and she encouraged him to work constantly and remain sober.The pair moved outside Paris, to Le Vésinet. By that time, Utrillo's afflictions had taken their toll. Too ill to work in the open air, he painted landscapes from the window, as well as scenes from memory and from postcards. He died in 1955 of a lung disease. In 1963, Lucie Valore founded the "Association Maurice Utrillo," which houses extensive documentation on the couple's work and that of Suzanne Valadon and André Utter, as well as an impressive art history library.

Above all, Utrillo has an eye for Montmartre, the old, picturesque, and relatively quiet artists' quarter as it existed before the First World War. He was fascinated by the sad little streets and miserable bistros of the industrial suburbs. It is true that he also painted some of the great cathedrals of France and panoramas of of Brittany and Corsica, as well as a few flower pieces. He will be known forever as the painter of the unheralded sights of the French capital.

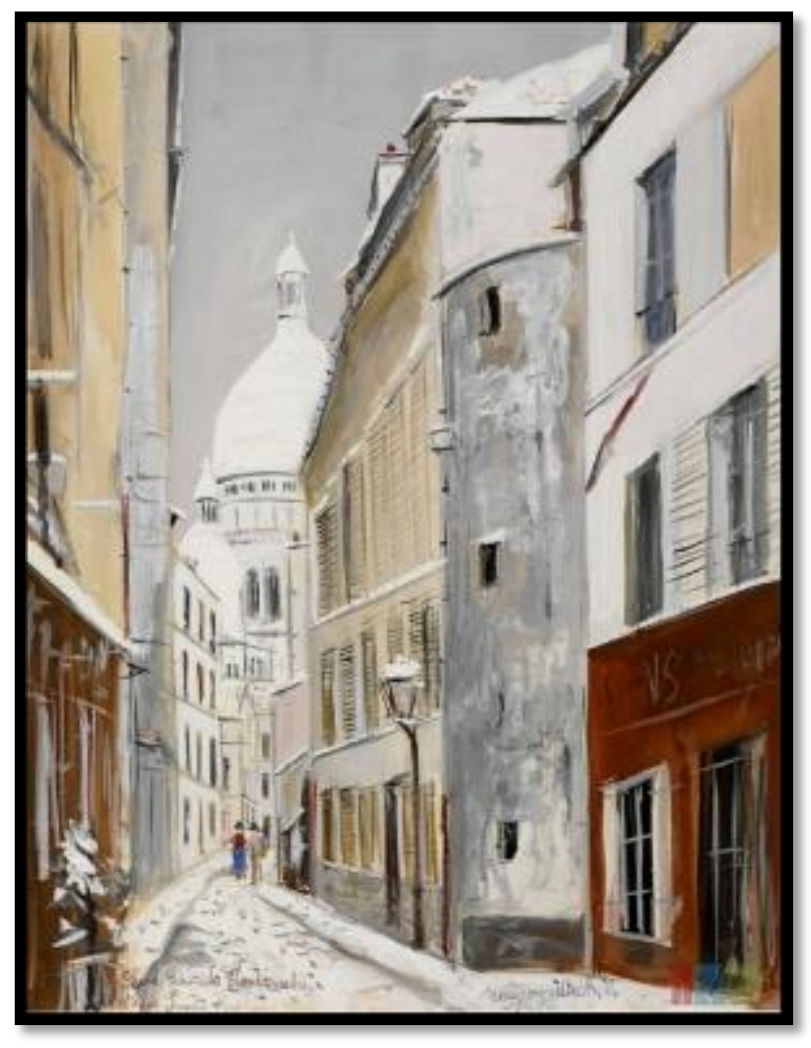

Figure 24

\section{Conclusions}

Landscape painting occupied a position of privilege in reflecting the nature of the place and links withing its civilization heritage. The artist expresses it in his own way and creates new aesthetic realities in his landscape paintings. His memory adds the highest value to the view and translates features of nature of this place in terms of form, feeling and influence through the ages.

Probably, the fact that Vincent van Gogh ( Figure 25) and Maurice Utrillo ( Figure 26) were deeply attached to the place could be attributed to the psychological states they went through which made them prefer isolation and loneliness. However, our main concern here is the deep attachment to the place, which produced works of art that history can never forget. Their art productions are considered among the most important landmarks of these cities. Thus, tourists must see the place through their paintings as if it represents that unseen depth of these places, that depth in which abstract beauty is concealed. It is the beauty which is related to the spirit of the place. The spirit that we cannot see but feel. 


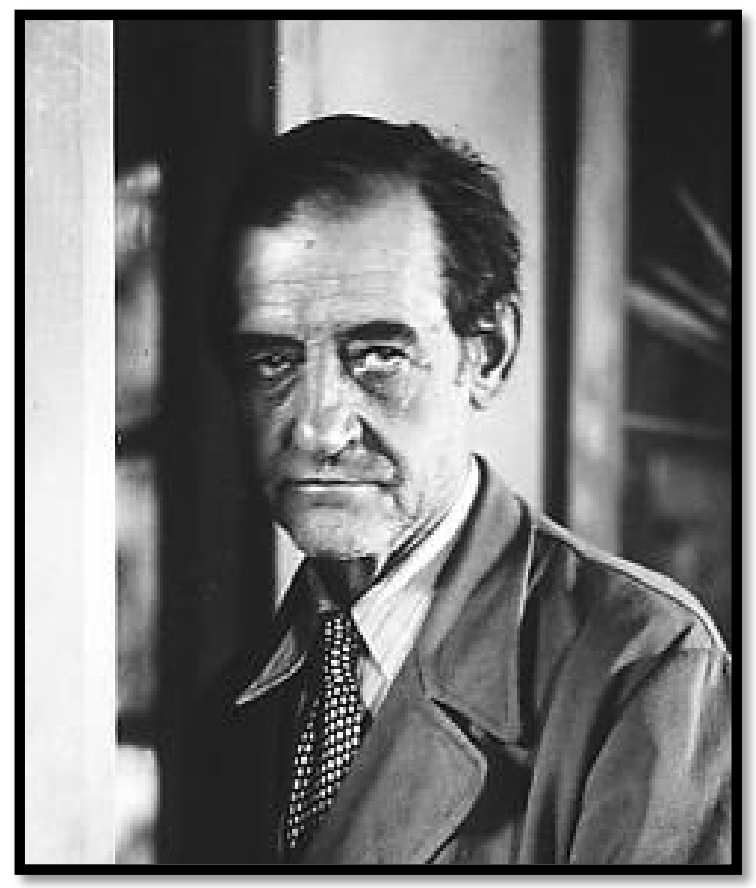

Figure 25

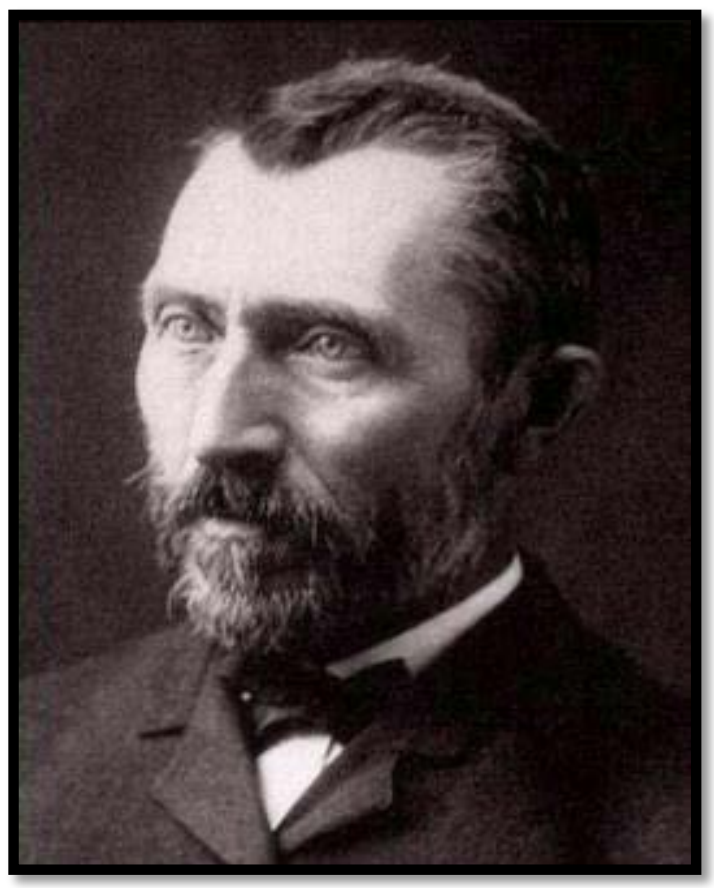

Figure 26

\section{References}

1. Foyle, J. (2015, May 22). Is it time to rethink our ideas about preserving world heritage? Retrieved August 30, 2017, from https://www.ft.com/content/545458d4-fae9-11e4-9aed-00144feab7de

2. Impact, T. N. (n.d.). Vincent van Gogh Gallery. Retrieved August 30, 2017, from http://www.vangoghgallery.com/

3. Kennedy, J\& Treuherz, J, "The Railway - Art in the age of steam, Walker Art Gallery, National Museums Liverpool, The Nelson- Atkins Museum of Art, Kansas City, Missouri, Yale University Press, New York.

4. Pessard, G. (1970, January 01). Nouveau dictionnaire historique de Paris, avec une préf. de Charles Normand : Pessard, Gustave : Free Download \& Streaming. Retrieved August 30, 2017, from https://archive.org/details/nouveaudictionna00pessuoft

5. Piper, D. (1984). The Illustrated Dictionary of Art \& Artists. Random House, New York.

6. Pregelj, Z. (2012, October 07). Surviving Transition. Retrieved August 30, 2017, from http://pensionerblog.blogspot.com.eg/2012/10/maurice-utrillo-sacre-coeur-de.html

7. S, D. M., Lvova, I., \& Fateyev, V. (1996). French painting. Parkstone ; St. Petersburg: : Bournemouth.

8. The Importance of Cultural Heritage. (2017, April 24). Retrieved August 30, 2017, from http://www.cultivatingculture.com/2013/04/05/the-importance-of-cultural-heritage/

9. Treble, R. " Van Gogh and his art ", Hamlyn.London, New York, Toronto.

10. What is Cultural Heritage? (n.d.). Retrieved August 30, 2017, from https://www.khanacademy.org/humanities/art-historybasics/beginners-art-history/a/what-is-cultural-heritage

11. Werner, A. (1953). Utrillo. Retrieved August 30, 2017, from http://www.rosings.com/cover.html

12. Wilson, J (2014) " Sun Rise ", Natural Living, p81, World Peace Communications.

13. Ruhrberg, K., Honnef, K., Schneckenburger, M., \& Fricke, C. (n.d.). Art of the 20th Century. 


\section{Table of figures}

\begin{tabular}{|c|c|}
\hline Figure & Data \\
\hline 1 & Langlios Bridge , Arles, France \\
\hline 2 & Van Gogh,(Langlios Bridge at Arles ) may,1888, Oil on canvas ,49.5 × $64.0 \mathrm{~cm}$. Arles ,.Cologne , wallra f.Richartz - Museum \\
\hline 3 & Statue of Frederic mistral in Arles. \\
\hline 4 & Statue of Van Gogh face in Arles. \\
\hline 5 & The place where 'The Yellow House' used to be, Arles, France. \\
\hline 6 & Van Gogh, ( The Yellow House) 1888 Oil on canvas 72.091 .5 cm . Arles, September , Montmartre, Paris, France. \\
\hline 7 & Van Gogh,(Wheat Field with Sheaves), June, 1888, Honolulu, Honolulu Museum of Art. \\
\hline 8 & Van Gogh, (Farmhouse in a Wheat Field), May, 1888, Amsterdam, Van Gogh Museum \\
\hline 9 & Van Gogh, (View from the wheat fields), 1888 , oil on canvas $73.054 .0 \mathrm{~cm}$.Arles, june,Paris,Musee Rodin \\
\hline 10 & Van Gogh, (Langlios Bridge at Arles with women washing), March 1888 , oil on canvas $54.0 \times 65.0$ cm, Arles. \\
\hline 11 & Van Gogh,(Orchad in blossom) April 1888, oil on canvas,72.5×92.0 cm .Arles, Amsterdam,Van Gogh Museum . \\
\hline 12 & Van Gogh,(Orchard in blossom), 1888,oil on canvas $72.4 \times 53.5 \mathrm{~cm}$. Arles , march - April, New york, the Metropolitan Museum \\
\hline 13 & Van Gogh, Avenue of Plane Tree near Arles Station(The Blue Train),1888 Oil on canvas 46×49.5cm,Musee Rodin, Paris. \\
\hline 14 & the district of Montmartre ,Paris . \\
\hline 15 & The Basilica of Sacred Heart of Paris, commonly known as "Sacre -Coeur" \\
\hline 16 & the Church of Saint Peter of Montmartre -one of the oldest surviving churches in Paris. \\
\hline 17 & Le Moulin de la Galette, a windmill and associated businesses in Montmartre , Paris \\
\hline 18 & the district of Montmartre ,Paris. \\
\hline 19 & Statue of Dalida , Montmartre, Paris, France. \\
\hline 20 & Maurice Utrillo ,( Moulin de la Galette) ,1930 , oil on canvas \\
\hline 21 & Maurice Utrillo,(Impssse Cottin Cul-de-sac in Paris. \\
\hline 22 & Maurice Utrillo Saint, Peter’s Church,oil on canvas , Montmartre ,1914, paris,muse de l' Orangerie Cottin , oil on cardboard 1910. \\
\hline 23 & MauriceUtrillo,(Church at Clignancourt), oil on canvas ,Montmartre ,1913-1915, Paris, musee de l' Orangerie \\
\hline 24 & $\begin{array}{l}\text { Maurice Utrillo, (Sacre-Coeur De Montmartre and the rue Saint-Rustique), gouache on paper mounted on canvas } 27 \text { x } 21 \text { in. Maurice } \\
\text { Utrillo, } 1937 \text {. }\end{array}$ \\
\hline 25 & Photo of Vincent van Gogh \\
\hline 26 & Photo of Maurice Utrillo. \\
\hline
\end{tabular}

